\title{
PROSEDUR PENJUALAN ALAT BERAT (TOYOTA FORKLIFT) PADA PT TRAKTOR NUSANTARA CABANG MAKASSAR
}

\author{
Ahmad Firdaus \\ Politeknik Informatika Nasional Makassar \\ Email:dauz4646@gmail.com
}

\begin{abstract}
This research paper was identified to measure procedure of sales of Heavy Equepment (Toyota Forklifts) at PT Traktor Nusantara branch Makassar. Furthermore this research used qualitatives descriptive method which described the observations and analyzes data. This research paper was the result of research conducted on 04 May to 25 May 2018. The results showed that the procedure of sale of Heavy Equepment (Toyota Forklifts) at PT Traktor Nusantara branch Makassar was in accordance with SOP (Standard Operational Co mpany). Documents and records used in the transaction of cash and credit sales at Pt Traktor Nusantara Makassar Branch was already effective, it can be seen from the documents and records that are used already complete, from ordering goods, credit, filing receipts, invoice, as well as documents of proof of delivery of the goods. As for the abstacles faced in the process of sale of heavy equipment, namely the process of payments made by the customer is often too late. The goods have arrived at the payout process is not finished.
\end{abstract}

Keyword: Prosedures, Cash sales, Credit sales.

\begin{abstract}
Abstrak
Penelitian ini bertujuan untuk mengetahui Prosedur Penjualan Alat Berat (Toyota Forklift) Pada PT Traktor Nusantara Cabang Makassar. Jenis penelitian yang digunakan adalah deskriptif kualitatif, yaitu penulis menggambarkan observasi dan menganalisa data-data yang diperoleh di lapangan. Penelitian dilakukan pada tanggal 04 Mei sampai 25 Mei 2018. Hasil penelitian menunjukkan bahwa Prosedur Penjualan Alat Berat (Toyota Forklift) Pada PT Traktor Nusantara Cabang Makassartelah sesuai dengan SOP (Standar Operasional Perusahaan). Dokumen-dokumen dan catatan yang digunakan dalam transaksi penjualan tunai dan kredit pada PT Traktor Nusantara Cabang Makassar sudah efektif, hal ini dapat dilihat dari dokumen dan catatan yang digunakan sudah lengkap, dari pemesanan barang, pengajuan kredit, kwitansi, invoice, serta dokumen bukti pengiriman barang. Adapun kendala yang dihadapi dalam penjualan alat berat yaitu proses pembayaran yang dilakukan oleh pelanggan sering terlambat terkadang barang telah sampai di tempat atau kantor tetapi proses pembayarannya belum selesai
\end{abstract}

Kata kunci: Prosedur, Penjualan Tunai, Penjualan Kredit. 


\section{PENDAHULUAN}

PT Traktor Nusantara Cabang Makassar atau sering disebut Traknus merupakan salah satu anak perusahaan milik Astra Internasional yang bergerak dalam distribusi, penyewaan dan kontrak, layanan purna jual dan peralatan bekas untuk keperluan Industri, Pertanian, Penggerak dan Energi serta Konstruksi Jalan. Perusahaan ini memiliki status kepemilikan saham gabungan antara PT Astra Internasional Tbk dan Sumitomo Corporation.

Perusahaan ini mengawali usahanya dengan menjadi distributor untuk Messey Fergusin Farm Tractor kemudian selanjutnya berturut-turut, perusahaan PT Traktor Nusantara menjadi distributorPerkins Engine, Toyota forklift,Toyota Industrial Equipment (2008). PT Traktor Nusantara memiliki visi dengan memilih produk dari perusahaan ini, konsumen mendapat jaminan akan nilai tambah dalam hal servis, pengoperasian dan pelatihan perawatan, serta pasokan suku cadang dan unit cadangan yang lengkap dan akurat, dilengkapi dengan teknisi yang berpengalaman serta servis yang menjangkau seluruh pelosok Indonesia yang akan membantu para konsumen. (Traknus. 2015. Sejarah Traktor Nusantara.

Seperti yang telah dijelaskan di atas bahwa PT Traktor Nusantara merupakan perusahaan yang bergerak dalam distribusi dan penyewaan alat berat maka perusahaan tersebut harus mampu bersaing dengan perusahaanperusahaan lain, untuk memperoleh keuntungan atau Profit Oriented, sehingga mampu berkembang menjadi perusahaan yang besar dan tangguh. Kesuksesan perusahaan dalam bisnis hanya bisa dicapaimelalui pengelolaan yang baik, khususnya pengelolaan manajemen keuangan sehingga modal yang dimiliki bisa berfungsi sebagaimana mestinya, penjualan barang maupun jasa merupakan sumber pendapatan perusahaan.Dalam melaksanakan penjualan kepada para konsumen, perusahaan dapat melakukannya secara tunai maupun kredit. Perusahaan akan lebih menyukai transaksi penjualan yang dapat dilakukan secara tunai, karena perusahaan akan segera menerima kas dan kas tersebut dapat segera digunakan kembali untuk mendapatkan pendapatan selanjutnya.

Para konsumen umumnya lebih menyukai bila perusahaan dapat melakukan penjualan secara kredit, karena pembayaran dapat ditunda. Dalam kenyataannya, penjualan kredit padaperusahaan biasanya jauh lebih besar dari penjualan tunai. (Teebriz. 2017. Pengertian Penjualan Tunai dan Penjualan.

Penjualan adalah jumlah yang dibebankan kepada pelanggan untuk barang dagang yang dijual, baik tunai maupun kredit. Penjualan kredit adalah penjualan barang dagangan dengan kesepakatan antara pembeli dan penjual pada saat transaksi yaitu pembayaran akan dilakukan pada waktu yang akan datang.Fokus utama perusahaan ini adalah melakukan penjualan secara tunai dankredit.

Penjualan tunai dilaksanakan oleh perusahaan dengan cara mewajibkan pembeli melakukan pembayaran harga barang terlebih dahulu sebelum barang diserahkan oleh perusahaan kepada pembeli. Setelah uang diterima oleh perusahaan barang kemudian diberikan kepada pembeli dan transaksi penjualan kemudain dicatat oleh perusahaan. 
Berbeda halnya dengan kredit, karena tidak akan segera menghasilkan penerimaan kas.Tapi menimbulkan akun piutang kepada konsumen atau yang biasa disebut dengan piutang usaha, dan barulah kemudian pada hari jatuh temponya terjadi aliran Cash Flow(kas masuk) yang berasal dari pengumpulan piutang usaha tersebut.Piutang usaha atau dagang yaitu transaksi yang paling banyak memungkinkan menciptakan piutang adalah penjualan barang secara kredit. Piutang usaha ini normalnya akan tertagih dalam periode waktu yang relatif pendek yaitu 30-60 hari yang akan dikelompokkan menjadi asset lancar.

Piutang usaha atau dagang adalah hak atau tagihan kepada pihak lainnya yang nantinya akan dimintai pembayarannya jika sudah waktunya. Tidak ada satupun perusahaan yang mengharapkan sebagian kredit yang dikeluarkan tidak bisa dibayar oleh debitur walaupun dalam proses pemberian kredit telah diteliti sebaikbaiknya. Namun, pada kenyataannya resiko tak tertagih atas sejumlah piutang pasti akan ditemui.Berdasarkan latar belakang permasalahan yang ada diatas, maka penulis tertarik untuk mengangkat judul yaitu: "Prosedur Penjualan Alat Berat (Toyota Forklift) Pada Pt Traktor Nusantara Cabang Makassar".

\section{TINJAUAN PUSTAKA}

\subsection{Pengertian Prosedur}

Dalam berbagai aktivitas, manusia sering kali dihadapkan dengan berbagai macam prosedur ataupun tata laksana pelaksanaan atau penggunaan.Lantas apa sih sebenarnya prosedur itu? Jika diartikan secara sederhana, prosedur merupakan seperangkat peraturan atau tata laksana dari sebuah aktivitas ataupun kegiatan tertentu.
Dalam pelaksanaan prosedur, ada beberapa aturan formal yang harus ditaati, yaitu :

a. Prosedur harus dijalankan sesuai dengan struktur, maksud dan ruang lingkupkegiatan.

b. Prosedur harus diterangkan oleh seorang penanggung jawab.

c. Prosedur harus dijalankan dengan menggunakan acuan berupa dokumen-dokumen terkait.

d. Prosedur harus diaplikasikan dengan menggunakan berbagai macam bahan, alat, dan juga dokumen yang sesuai.

e. Prosedur harus dilengkapi dengan informasi ataupun catatan pengendalian.

f. Prosedur harus dilengkapi dengan lampiran-lampiran yang sesuai.

g. Prosedur harus dikontrol dengan menggunakan dokumentasi ataupun rekaman penjalanan prosedur.

h. Menurut Lilis Puspitawati dan Dewi Anggadini dalam bukunya yang berjudul "Sistem Informasi Akuntansi" (2011:23) menyatakan bahwa:

"Prosedur merupakan serangkaian langkah atau kegiatan klerikal yang tersusun secara sistematis berdasarkan urutan-urutan yang terperinci dan harus diikuti untuk dapat menyelesaikan suatu permasalahan".

Dari pengertian di atas mengenai prosedur dapat disimpulkan bahwa prosedur merupakan urutan-urutan yang terperinci yang harus dijalankan sesuai dengan prosedur yang telah ada sebelumnya. Menurut Mulyadi dalam bukunya yang berjudul "Sistem Akuntansi" (2016:4) menyatakan bahwa:

"Prosedur adalah urutan kegiatan klerikal, biasanya melibatkan beberapa orang dalam suatu departemen atau lebih, yang dibuat 
untuk menjamin penanganan secara seragam transaksi perusahaan yang terjadi berulang".

Dari pengertian di atas mengenai prosedur dapat disimpulan bahwa prosedur merupakan tahap demi tahap yang melibatkan beberapa orang atau lebih dalam proses demi tercapainya suatu tujuan dalam perusahaan.

Sedangkan dalam Kamus Besar Bahasa Indonesia (2013:899) menjelaskan bahwa:

"Prosedur adalah tata cara atau langkah-langkah yang harus ditempuh atau dipenuhi sebagai suatu syarat untuk mendapatkan sesuatu". Tata cara adalah suatu peraturan atau ketentuan yang dilakukan tahap demi tahap dan sesuai alur yang telah ditentukan. Sedangkan syarat merupakan suatu keharusan atau tuntutan yang harus dipenuhi.

Dari beberapa pengertianmengenai prosedur diatas dapat disimpulkan bahwa prosedur merupakan suatu urutan kegiatan yang melibatkan beberapa orang atau lebih didalam satu departemen dimana urutan kegiatan tersebut digunakan untuk menjamin adanya penanganan terhadap transaksi-transaksi yang terjadi berulang-ulang dalam satu perusahaan.

\subsection{Pengertian Penjualan}

Penjualan merupakan kegiatan penting dari suatu perusahaan guna menunjang kelangsungan hidup perusahaan. Menurut Moekijat dalam bukunya "Kamus Manajemen" cetakan kelima (2000:48) menyatakan bahwa:

"Melakukan penjualan adalah suatu kegiatan yang ditujukan untuk mencari pembeli, mempengaruhi dan memberi petunjuk agar pembelian dapat menyesuaikan kebutuhannya dengan produksi yang ditawarkan serta mengadakan perjanjian mengenai harga yang menguntungkan kedua belah pihak".

Sementara itu,Basu Swasta (2015:1) dalam bukunya Manajemen Penjualanmenyatakan bahwa "Menjual adalah ilmu dan seni mempengaruhi pribadi yang dilakukan oleh penjual untuk mengajak orang lain agar bersedia membeli barang dan jasa yang ditawarkan".

Sedangkan, menurut Winardi (2013:26) dalam bukunyaManajemen Perubahan (The Management of Change),menyatakan bahwa:

"Penjualanadalah berkumpulnya seorang pembeli dan penjual dengan tujuan melaksanakan tukar menukar barang dan jasa berdasarkanpertimbangan yang berharga misalnya pertimbangan uang".

Dari beberapa pengertian penjualan diatas dapat disimpulkan bahwa penjualan merupakan kegiatan berupa menjual barang dan jasa yang dilakukan antara dua belah pihak (pembeli dan penjual) yang dapat dilakukan baik secara tunai maupun secara kredit.

\subsection{Pengertian Prosedur Penjualan}

Dari pengertian diatas dapat disimpulkan bahwa prosedur penjualan adalah urutan kegiatan sejak diterimanya pesanan dari pembeli, pengiriman barang, pembuatan faktur (penagihan) dan pencatatan penjualan yang melibatkan beberapa orang dalam satu departemen atau lebih, yang dibuat untuk menjamin penanganan secara seragam transaksi perusahaan yang terjadi berulang-ulang. 
Prosedur penjualan digunakan untuk melayani pembeli yang akan membeli barang. Prosedur ini dilaksanakan oleh bagian penjualan dengan mengisi faktur penjualan tunai dengan informasi antara lain jenis buku, kuantitas, harga satuan dan total harga. Prosedur penjualan melibatkan beberapa bagian dalam perusahaan dengan maksud agar penjualanyang terjadi dapat diawasi dengan baik. Bagian-bagian yang terlibat adalah penjualan tunai dan penjualan kredit yaitu:

a. Prosedur Penjualan Tunai

Penjualan dilakukan oleh perusahaan dengan cara mewajibkan pembeli melakukan pembayaran harga barang terlebih dahulu sebelum barang diserahkan oleh perusahaan kepada pembeli. Setelah uang diterima oleh perusahaan, barang kemudian diberikan pada pembeli dan transaksi penjualan kemudian dicatat oleh perusahaan.

Dokumen-dokumen yang digunakan dalam prosedur penjualan tunai adalah sebagai berikut :

1) Penawaran Harga (Quotation)

2) Surat Perjanjian Jual Beli (SPJB)

3) Purchase Order (PO)

4) Surat Permohonan Pembayaran

5) Kwitansi

6) Berita Acara Serah Terima (BAST)

7) Invoice

Catatan-catatan yang digunakan dalam prosedur penjualan tunai adalah :

1) Jurnal Penjualan

2) Jurnal Penerimaan Kas

3) Jurnal Umum

4) Kartu Persediaan

Unit organisasi yang terkait dalam prosedur penjualan tunai adalah sebagai berikut:

1) Bagian Order Penjualan

2) Bagian Kassa
3) Bagian Gudang

4) Bagian Pengiriman Barang

5) Bagian Kartu Persediaan

6) Bagian Jurnal, Buku Besar dan Laporan

b. Prosedur Penjualan Kredit

Berbeda dengan penjualan tunai, uang langsung dibayar oleh pembeli pada waktu transaksi penjualan, maka penjualan kredit pembayarannya dapat diterima beberapa waktu kemudian sesuai dengan perjanjian yang dibuat oleh penjual dan pembeli. Untuk mendapatkan pengawasan intern yang baik pada penjualan kredit perlu disusun prosedur tertentu yang menggambarkan arus dokumen dan tata cara pencatatan penjualan kredit yang harus diperhatikan adalah :

1) Penawaran Harga (Quotation)

2) Surat Perjanjian Jual Beli (SPJB)

3) Purchase Order (PO)

4) Surat Permohonan Pembayaran (Down Payment)

5) Kwitansi

6) Berita Acara Serah Terima (BAST)

7) Invoice (Down Payment)

Catatan akuntansi yang digunakan dalam prosedur penjualan kredit adalah:

1) Jurnal Penjualan

2) Kartu Piutang

3) Kartu Persediaan

Unit-unit organisasi yang terkait dalam prosedur penjualan kredit adalah:

1) Bagian Order Penjualan

2) Bagian Kredit

3) Bagian Gudang

4) Bagian Pengiriman Barang

5) Bagian Piutang

6) Bagian Kartu Persediaan dan Kartu Biaya

7) Bagian Jurnal Buku Besar dan Laporan 


\subsection{Fungsi-Fungsi Yang Terkait Dalam Prosedur Penjualan.}

Prosedur penjualan melibatkan beberapa bagian dalam perusahaan dengan maksud agar penjualan yang terjadi dapat diawasi dengan baik.Bagian-bagian yang terkait dalam prosedur penjualan adalah bagian pesanan penjualan, bagian kredit, bagian gudang, bagian pengiriman dan bagian billing atau faktur. Fungsi dari tiap-tiap bagian ini adalah sebagai berikut:

a. Bagian pesanan penjualan (Sales Order Department)

Dalam perusahaan kecil, fungsi pesanan penjualan dapat dipegang oleh seorang karyawan dalam bagian penjualan.Tetapi dalam perusahaan besar bagian pesanan penjualan merupakan bagian yang berdiri sendiri dibawa bagian penjualan. Untuk kedua keadaan, bagian pesanan penjualan mempunyai fungsi sebagai berikut :

1) Mengawasi semua pesanan yang diterima.

2) Memeriksa urat pesanan yang diterima dari pelanggan atau salesman dan melengkapi informasi yang kurang berhubungan dengan spesifikasi produk dan tanggal pengiriman.

3) Meminta persetujuan penjualan kredit dari bagian kredit.

4) Menentukan tanggal pengiriman. Apabila uangnya lebih dari satu menentukan dari gudang mana yang akan dilakukan pengiriman.

5) Membuat surat perintah pengiriman (Shipping Orders) dan back orders berserta tembusantembusannya.
6) Membuat catatan mengenai pesananpesanan yang diterima dan mengikuti pengirimannya sehingga dapat diketahui pesanan-pesanan mana belum terpenuhi.

7) Mengadakan hubungan dengan pembeli mengenai barang-barang yang dikembalikan oleh pembeli, membuat catatan dan mengeluarkan bukti memorial (Journal voucher) untuk bagian piutang.

8) Mengawasi pengiriman barangbarang untuk contoh (sampel).

b. Bagian kredit

Dalam prosedur penjualan, setiap pengiriman barang untuk memenuhi pesanan pembelian yang syaratnya kredit harus mendapatkan persetujuan dari bagian kredit agar dapat memberikan persetujuan, bagian kredit menggunakan catatan yang dibuat oleh bagian piutang untuk tiap-tiap pelanggan mengetahui sejarah kreditnya, jumlah maksimum dan ketetapan waktu pembayarannya. Persetujuan dari bagian kredit biasanya ditunjukkan dalam formulir surat perintah pengiriman yang diterima dari bagian pesanan penjualan.

Kadang-kadang terjadi surat perintah pengiriman dari bagian pesanan penjualan langsung didistribusikan pada masing-masing bagian yang bersangkutan dan bagian kredit menerima satu lembar kemudian menandatangani untuk persetujuan atau menolaknya. Kalau dalam hal pesanan ini tidak disetujui oleh bagian kredit maka bagian pesanan penjualan memberitahukan kepada bagian pengiriman agar barang-barangnya tidak jadi dikirim.Prosedur ini biasanya untuk menyingkat waktu dan untuk langganan-langganan lama.Apabila 
pembeli merupakan langganan baru maka semua lembar surat perintah pengiriman dari bagian pesanan penjualan diserahkan ke bagian kredit. Sesudah disetujui baru didistribusikan kepada masing-masing bagian.

c. Bagian gudang

Dalam hubungannya dengan penjualanbagian gudang bertugas untuk menyiapkan barang seperti yang tercantum dalam surat perintah pengiriman. Barang-barang ini diserahkan ke bagian pengiriman untuk disiapkan dan dikirimkan ke pembeli.

\section{d. Bagian pengiriman}

Bagian pengiriman bertugas untuk mengirimkan barang-barang pada pembeli. Pengiriman hanya boleh dilakukan apabila ada surat perintah pengiriman yang sah. Selain itu bagian pengiriman juga bertugas mengirimkan kembali barang-barang kepada penjual yang keadaannya tidak sesuai dengan yang dipesan.

e. Bagian billing (pembuatan faktur atau penagihan)

Tugas bagian billing atau pembuatan faktur adalah :

1) Membuat (menerbitkan) faktur penjualan dan tebusan-tebusannya (kadang-kadang tidak membuat faktur tetapi melengkapi data harga dan perkalian dalam faktur)

2) Menghitung biaya kirim penjualan dan Pajak Pertambahan Nilai.

3) Memeriksa kebenaran penulisan dan perhitungan-perhitungan dalam faktur.

\subsection{Tujuan Penjualan}

Pada umumnya perusahaan memiliki tiga tujuan umum dalampenjualan seperti yang dirumuskan oleh Basu Swastha (2015:27), adalah:

a. Berusaha mencapai volume penjualan

b. Berusaha mendapatkan laba tertentu

c. Menunjang pertumbuhan perusahaa.

Usaha untuk mencapai ketiga tujuan tersebut, tidak sepenuhnya hanya dilakukan oleh pelaksana penjualan atau para ahli penjualan.Dalam hal ini perlu adanya kerjasama yang baik didalam perusahaan.

\subsection{Faktor-faktor yang Mempengaruhi Penjualan}

Adapun faktor-faktor yang mempengaruhi kegiatan penjualan antar lain:

a. Kondisi dan Kemampuan Pasar

Disini penjual harus dapat meyakinkan pembeli agar berhasil mencapai sasaran penjualan yang diharapkan untuk maksud tersebut, penjual harus dapat memahami beberapa masalah yang cukup penting:

1) Jenis dan karakteristik barang atau jasa yang ditawarkan

2) Harga produk

3) Syarat penjualan, seperti; pembayaran, pengantaran, garansi dan sebagainya.

b. Kondisi Pasar

Hal yang harus diperhatikan pada kondisi pasar antara lain :

1) Jenis pasarnya, apakah pasar konsumen, pasar industri, pasar pemerintahan atau pasar Internasional

2) Kelompok pembeli dan segmen pasarnya

3) Daya beli

4) Frekuensi pembeliannya

5) Keinginan dan kebutuhan 
c. Modal

Apakah modal kerja perusahaan mampu untuk mencapai target penjualan yang dianggarkan seperti untuk:

1) Untuk membiayai penelitian pasar yang dilakukan.

2) Kemampuan membiayai usaha-usaha untuk mencapai target penjualan.

3) Kemampuan membeli bahan mentah untuk dapat memenuhi target penjualan.

\subsection{Kerangka Pikir}

PT Traktor Nusantara Cabang Makassar adalah perusahaan yang bergerak dalam bidang penjualan alat berat yang bergerak dalam distribusi, penyewaan dan kontrak, layanan purna jual dan peralatan bekas untuk keperluan Industri, Pertanian, Penggerak dan Energi serta Kontruksi Jalan. Dalam prosedur penjualan alat berat bertujuan untuk mengetahui bagaimana prosedur penjualan yang digunakan dalam perusahaan apabila penjualannya merupakan penjualan kredit maupun penjualan tunai.

Adapun kerangka pikir yang telah diuraikan dapat digambarkan dalam bentuk struktur sebagai berikut :

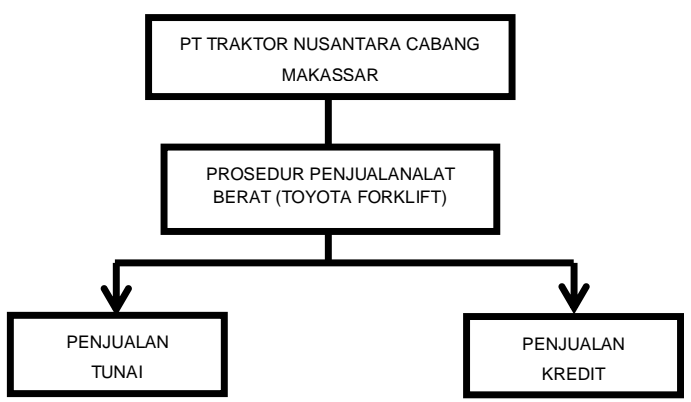

Gambar 2.1: Skema Kerangka Pikir

Keterangan :

Adapun penjelasan dari kerangka pikir di atas yaitu untuk menentukan arah atau rencana sebuah bisnis maka suatu perusahaan memerlukan prosedur penjualan yang baik, di mana penjualan adalah aktivitas yang bertujuan untuk mencari pembeli atau mempengaruhi konsumen agar terdapat suatu transaksi yang dilakukan oleh kedua pihak dengan alat pembayaran yang sah dan saling menguntungkan bagi kedua pihak tersebut. Adapun prosedur penjualan alat berat yang dipilih perusahaan untuk dijalankan yaitu prosedur penjualan tunai dan prosedur penjualan kredit.

\section{METODE PENELITIAN}

\subsection{Metode Analisis Data}

Penelitian ini dilakukan dengan menggunakan deskriptif kualitatif untuk mendapatkan data yang valid dalam penelitian di mana data-data yang berhasil dikumpulkan, diolah dan kemudian dianalisis, yang merupakan suatu cara atau langkah untuk mengolah data primer dan sekunder dalam memecahkan masalah penelitian. Tahap analisa data terdapat empat tahap yaitu sebagai berikut :(Zuhrotul Aini Manzilah. 2017. Tinjauan Disiplin Kerja Karyawan Terhadap PT Traktor Nusantara Cabang Makassar. Tugas Akhir Administrasi Keuangan).

a. Pengumpulan Data: Pengumpulan data dilakukan melalui metode wawancara dan observasi. Kemudian data-data yang sudah terkumpul dibuatkan transkipnya.

b. Reduksi Data: Meredukasi data berarti merangkum, memiliki hal-hal yang pokok, menfokuskan atau pemusatan pada hal-hal yang penting. Dengan demikian data yang telah diredukasi akan memberikan gambaran yang lebih jelas, serta mempermudah peneliti untuk melakukan pengumpulan data setiap penelitian akan dipandu oleh tujuan yang akan dicapai. 
c. Penyajian Data: Setelah data direduksi, maka langkah selanjutnya adalah menyajikan data, dalam penelitain kualitatif penyajian data dilakukan dalam bentuk uraian singkat, dirangkum, ditafsirkan, dijelaskan dan sejenisnya. Sehingga adanya kemungkinan penarikan kesimpulan bahwa penyajian data akan mempermudah untuk memahami apa yang terjadi dan merencanakan yang akan dilakukan selanjutnya.

d. Penarikan Kesimpulan: Pada tahap ini peneliti menarik kesimpulan dari hasil analisis data yang sudah
dilakukan.Penarikan kesimpulan dalam penelitian kualitatif mungkin dapat menjawab rumusan masalah yang dirumuskan sejak awal.

\section{HASIL DAN PEMBAHASAN}

\subsection{Penyajian Data Hasil Penelitian}

Penyajian data yang digunakan penulis adalah dengan menggunakan teknik pengumpulan data yaitu studi kepustakaan dan studi lapangan serta analisis data yaitu kualitatif deskriptif yang diperoleh langsung dari kantor PT Traktor Nusantara Cabang Makassar.

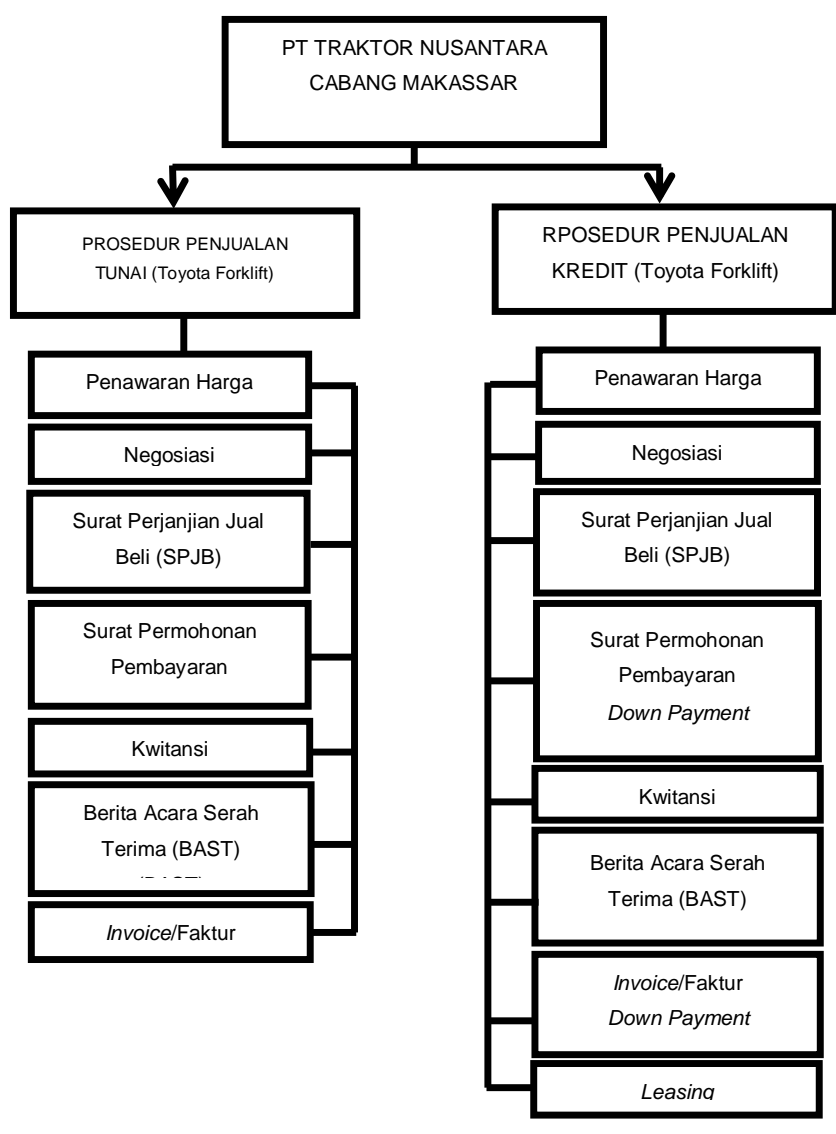

Gambar 4.9: Skema Penyajian Data Hasil Penelitian 
Keterangan :

\section{a. Prosedur Penjualan Tunai (Toyota Firklift)}

Tahap pertama dari prosedur penjualan tunai (Toyota Forklift) adalah dibuat dan dikirimkan surat penawaran hargaoleh penjual (sales) kepada calon pembeli untuk menawarkan barang sesuai kebutuhan yang diinginkan setelah adanya permintaan penawaran dari pembeli. Selanjutnya adalah proses negosiasi, yaitu pembeli dan penjual melakukan proses tawar-menawar sebelum melakukan transaksi pembelian suatu barang. Kemudian pemberian Surat Perjanjian Jual Beli (SPJB), yaitu setelah pihak pembeli dan penjual menyetujui kesepakatan yang telah dibuat maka pihak perusahaan akan mengeluarkan Surat Perjanjian Jual Beli (SPJB) untuk dapat diproses lebih lanjut. Setelah itu pemberian surat permohonan pembayaranyaitu pihak perusahaan mengeluarkan Surat Permohonan Pembayaran yang akan ditujukan kepada pihak pembeli agar dapat melakukan transaksi secepatnya sehingga barang tersebut dapat diambil langsung ataupun diantarkan ke alamat pembeli. Kemudian pemberian kwitansi oleh perusahaan sebagai bukti bahwa traksaksi tersebut telah selesai. Setelah transaksi selesai maka pihak perusahaan akan memberikan Berita Acara Serah Terima (BAST) di mana dokumen ini harus ditandatangani pada saat proses penyerahan barang sebagai bukti bahwa barang tersebut telah diterima oleh pembeli. Dan proses terakhir adalah penyerahan Invoice atau faktur di mana invoice ini merupakan bukti bahwa pembelian barang tersebut telah selesai.

\section{b. Prosedur Penjualan Kredit (Toyota Forklift)}

Tahap pertama dari prosedur penjualan kredit (Toyota Forklift) adalah dibuat dan dikirimkan surat penawaran hargaoleh penjual (sales) kepada calon pembeli untuk menawarkan barang sesuai kebutuhan yang diinginkan setelah adanya permintaan penawaran dari pembeli. Selanjutnya adalah negosiasi, yaitu pembeli dan penjual melakukan proses tawar-menawar sebelum melakukan transaksi pembelian suatu barang. Kemudian pemberian Surat Perjanjian Jual Beli (SPJB) yaitu pihak pembeli dan penjual telah menyetujui kesepakatan yang telah dibuat maka pihak perusahaan akan mengeluarkan Surat Perjanjian Jual Beli (SPJB) untuk dapat diproses lebih lanjut. Setelah itu pemberian surat permohonan pembayaranyaitu pihak perusahaan mengeluarkan Surat Permohonan Pembayaran atau down payment (DP) yang akan ditujukan kepada pihak pembeli agar dapat melakukan transaksi secepatnya sehingga barang tersebut dapat diambil langsung ataupun diantarkan ke alamat pembeli. Kemudian pemberian kwitansi oleh perusahaan sebagai bukti bahwa traksaksi tersebut telah selesai. Setelah kesepakatan telah disetujui bahwa penjualan tersebut merupakan penjualan kredit maka pihak perusahaan memberikan dokumen Berita Acara Serah Terima (BAST) yaitu dokumen ini harus ditandatangani pada saat proses penyerahaan barang sebagai bukti bahwa barang tersebut telah diterima oleh pembeli. Selanjutnya penyerahan invoice/faktur atau Down Payment (DP) yaitu invoice ini merupakan bukti bahwa pembelian barang secara kredit tersebut telah selesai. Dan proses terakhir adalah leasing yaitu proses pembayaran berikutnya melalui pihak ketiga. 
Tetapi yang menjadi perbandingan antara prosedur penjualan tunai dan prosedur penjualan kredit (Toyota Forklift) adalah Penjualan Tunai menggunakan proses pembayaran yang langsung secara tunai di mana pihak pembeli menyerahkan uang sebagai bukti pembayaran sebesar harga barang yang dibeli. Sedangkan Penjualan Kredit tersebut menggunakan proses pembayarannya yaitu Down Payment (DP), di mana proses ini, pembeli hanya membayar 20\% (dua puluh persen) dari harga unit sesuai dengan harga yang telah disepakati perusahaan namun sisanya yang $80 \%$ (delapan puluh persen) akan dibayar melalui proses leasing yaitu pembiayaan dalam bentuk penyedian modal untuk digunakan selama jangka waktu tertentu berdasarkan pembayaran secara berkala.

\subsection{Pembahasan}

\section{a. Prosedur Penjualan Alat Berat (Toyota Forklift)}

1) Penawaran harga (Quotation) adalah surat penawaran yang diberikan kepada pelanggan setelah adanya permintaan penawaran. Penawaran harga (Quotation)memiliki beberapa hal pokok yang tercantum dalam surat, yaitu:

a) Data perusahaan termasuk alamat, nomor telepon, sales dan pihak perusahaan yang memiliki posisi penting dalam penjualan.

b) Kode atau nomor barang yang diminta.

c) Jumlah barang yang diminta.

d) Diskon atau pajak. Pajak umumnya $10 \%$ harga barang.

e) Total harga barang dan biaya kirim.

f) Tata cara pembayaran, cash on delivery atau cash before delivery atau jika pihak perusahaan sudah sering membeli dan kenal dengan vendor, ada term-nya. Misalnya pembayaran $\mathrm{H}+7$ setelah barang diterima.

g) mendapatkan informasi nomor rekening pembeli agar kita dapat menginfokan ke bagian finance untuk mentrasfer uang tersebut.

2) Negosiasi

Negosiasi adalah bentuk interaksi sosial yang bertujuan untuk mencapai kesepakatan diantara pihak-pihak yang mempunyai kepentingan yang berbeda. Kedua pihak yang melakukan negosiasi mempunyai hak terhadap hasil yang akan disepakati. Hasil akhir negosiasi harus mempunyai persetujuan dari semua pihak sehingga semua pihak menerima hasil akhir dengan kesepakatan bersama. Negosiasi tersebut mempunyai ciri-ciri diantaranya :

a) Menghasilkan kesepakatan (yang paling menguntungkan)

b) Mengarah pada tujuan praktis

c) Memprioritaskan kepentingan bersama

d) Merupakan sarana untuk mencari penyelesaian.

3) Surat Perjanjian Jual Beli (SPJB) atau Purchase Order (PO)

Surat Perjanjian Jual beli (SPJB) adalah surat yang dibuat pihak penjual dan pihak pembeli yang berisi kesepakatan mengenai jual beli. Pihak penjual sepakat untuk memenuhi kewajibannya menyerahkan barang tertentu dan berhak memperoleh imbalan uang tertentu pula.Pembeli sepakat untuk melaksanakan kewajiban menyerahkan uang tertentu dan berhak menerima barang tertentu pula. 
Adapun dalam pembuatan surat perjanjian jual beli mempunyai beberapa syarat yaitu sebagai berikut ini:

a) Isi surat sudah disepakati oleh pihakpihak yang terkait.

b) Isi surat sifatnya tidak menekan pihak lain.

c) Penyusunan surat perjanjian jual beli atas dasar musyawarah bersama.

4) Purchase Order (PO) merupakan sebuah kontrak yang membentuk kesepakatan antara pembeli dan penjual mengenai barang yang ingin dibeli oleh pihak pembeli.

Adapun beberapa syarat dalam pembuatan Purchase Order (PO) yaitu sebagai berikut ini:

a) Mencantumkan identitas perusahaan dengan jelas dalam purchase order.

b) Mencantumkan detail yang pembeli pesan, seperti merek, nama barang, jumlah dan informasi lainnya.

c) Cantumkan nomor PO (purchase order). Nomor ini sangat penting untuk melakukan penelusuran apabila ada kekeliruan ataupun permasalahan

5) Surat Penagihan Pembayaran

Surat Penagihan Pembayaran ini dibuat dan dikirimkan oleh penjual kepada pembeli untuk mengingatkan bahwa Anda harus melakukan pembayaran.Kewajiban melakukan pembayaran ini dikarenakan Anda masih memiliki hutang kepada penjual atas barang yang Anda beli.

Surat penagihan pembayaran ini memiliki beberapa hal pokok yang tercantum dalam surat, yaitu:
a) Penjual meminta Anda sebagai pembeli untuk segera melunasi hutang.
b) Mencantumkan alamat rekening perusahaan.

c) Mencantumkan bukti bahwa Anda belum melunasi atau membayar hutang.

d) Menjelaskan detail pesanan, pengiriman dan faktur atas pembelian Anda.

e) Mengingatkan tanggal jatuh tempo.

f) Menuliskan jumlah hutang yang harus di bayar.

g) Menuliskan harapan agar Anda sebagai pembeli untuk segera membayar sesuai dengan batas waktu.

Beberapa surat penagihan pembayaran memberikan waktu selama 2 minggu setelah batas jatuh tempo untuk dikirimkan surat penagihan yang kedua. Jika dalam surat tagihan yang kedua, pembeli belum juga melunasi tagihan, maka akan dikirmkan surat penagihan yang ketiga. Masing-masing penjual memiliki batas akhir terhadap surat penagihan yang dikirimkan, bisa 3 kali atau selama mendapatkan itikad baik dari pembeli. Apabila setelah surat penagihan ketiga pembeli tidak merespon apapun maka permasalahan tagihan ini bisa dibawa hingga ranah hukum. Pembeli bisa dikenakan sanksi sesuai dengan hukum yang berlaku.

6) Kwitansi

Kwitansi adalah dokumen yang dijadikan sebagai tanda bukti transaksi pembayaran yang ditandatangani oleh penerima uang.Kwitansi yang sudah diisi dengan berbagai keterangan pembayaran dan telah ditandatangani oleh penerima uang selanjutnya bisa diserahkan kepada yang membayar sejumlah uang tersebut.

7) Berita acara serah terima (BAST)

Berita acara serah terima barang merupakan salah satu dokumen penyerahan barang yang cukup penting. 
Surat ini sebaiknya segera dibubuhkan tanda tangan saat ada prosesi penyerahan suatu barang dari satu pihak ke pihak lain.Sehingga bila suatu saat terjadi perselisihan maka berita acara tersebut dapat dijadikan alat pembuktian penyerahan barang.Dokumen ini memang tampak sederhana, Namun tidaklah sesederhana masalah yang ditimbulkannya dikemudian hari.

8) Invoice atau Faktur

Invoice atau faktur adalah dokumen tagihan yang dibuat oleh penjual dalam suatu transaksi barang atau unit yang berisi jumlah pembayaran. Adapun unsur-unsur dalam pembuatan invoice sebagai berikut:

1) Data perusahaan penagih (pembuat invoice) yang terdiri dari nama $\mathrm{PT} / \mathrm{CV} /$ toko, alamat dan nomor Telepon.

2) Nomor invoice atau nomer surat faktur transaksi, atau istilah lainnya Purchase Order (PO)

3) Nomer pengiriman, Atau istilah lainnya nomer Delivery Order(DO)

4) Data orang atau PT perusahaan yang diberi invoice (meliputi nama dan nomer telepon)

5) Data barang atau jasa yang dibeli (meliputi nama barang atau unit, deskripsi, harga barang, ongkos kirim dan total harga)

6) Tanggal pembuatan invoice atau faktur

7) Cara atau Metode Pembayaran yang bisa dipilih.

8) Leasing (sewa guna usaha)adalah sebagai perusahaan yang melakukan aktivitas pembiayaan dalam bentuk peminjaman modal dan sudah melakukan perjanjian atau kesepakatan terlebih dahulu. Jadi bagi perusahaan yang modalnya kurang atau menengah, dengan melakukan perjanjian leasing akan membantu untuk menjalankan perusahaannya. Perusahaan dapat memperoleh barang-barang modal untuk operasional dengan mudah dan cepat. Setelah leasing selesai, perusahaan dapat membeli barang modal atau mengembalikannya pada akhir jangka waktu perjanjian leasing.

Menurut Dwi Susangka salah satu karyawan PT Traktor Nusantara Cabang Makassar mengatakan bahwa "PT Traktor Nusantara Nusantara Cabang Makassar terdapat dua jenis penjualan yaitu penjualan tunai dan kredit di mana penjualan tunai lebih dominan digunakan daripada penjualan kredit karena perusahaan akan lebih menyukai transaksi penjualan yang dapat dilakukan secara tunai dan perusahaan akan segera menerima kas dan kas tersebut dapat segera digunakan kembali untuk mendapatkan pendapatan selanjutnya".

\section{b. Kendala-Kendala Yang Dihadapi}

Pada prosedur penjualan alat berat, prosedur ini sudah berjalan sesuai dengan yang diharapkan, akan tetapi dalam transaksi penjualan jika terus dilakukan prosedur seperti ini kemungkinan akan menimbulkan ketidak akuratan pendapatan yang dihasilkan.

Menurut Dwi Susangka salah satu karyawan PT Traktor Nusantara Cabang Makassar mengatakan bahwa "Adapun kendala yang dihadapi dalam prosedur penjualan alat berat (Toyota Forklift) yaitu adanya hambatan dalam proses pembayaran yang dilakukan oleh pembeli atau pelanggansering terlambat, yang terkadang barang tersebut telah 
sampai di tempat atau kantor tetapi proses pembayarannya belum selesai".

\section{PENUTUP}

\subsection{Simpulan}

Berdasarkan hasil pembahasan penelitian mengenai Prosedur Penjualan Alat Berat (Toyota Forklift) pada PT Traktor Nusantara Cabang Makassar yaitu:

1. Terdapat beberapa prosedur penjualan tunai dan kredit alat berat (Toyota Forklif) sebagai berikut:

a. Prosedur penjualan tunai alat berat (Toyota Forklift) tahap pertama adalah Penawaran harga (Qoutation), Negosiasi, Surat Perjanjian Jual Beli (SPJB), Surat Permohonan Pembayaran, Kwitansi, Berita Acara Serah Terima (BAST) dan terakhir Invoice atau Faktur Pajak.

b. Prosedur penjualan kredit alat berat (Toyota Forklift) tahap pertama adalah Penawaran harga (Qoutation), Negosiasi, Surat Perjanjian Jual Beli (SPJB), Surat Permohonan Pembayaran atau Down payment, Kwitansi, Berita Acara Serah Terima (BAST), Invoice/fakturatau Down payment dan terakhir Leasing.

c. Prosedur Penjualan Alat Berat (Toyota Forklift) pada PT Traktor Nusantara Cabang Makassar dapat disimpulkan bahwa kenyataan yang terjadi telah sesuai dengan SOP (Standar Operasional Perusahaan). Dokumen-dokumen dan catatan yang digunakan dalam transaksi penjualan tunai dan kredit pada PT Traktor Nusantara Cabang Makassar sudah efektif, hal ini dapat dilihat dari dokumen dan catatan yang digunakan sudah lengkap, dari pemesanan barang, pengajuan kredit, kwitansi, invoice, serta dokumen bukti pengiriman barang.

2. Kendala-kendala yang dialami dalam Prosedur Penjualan Alat Berat (Toyota Forklift) pada PT Traktor Nusantara Cabang Makassar.

Berdasarkan hasil wawancara dan penelitian yang dilakukan, diperoleh informasi tentang kendala dalam Prosedur Penjualan Alat Berat (Toyota Forklift) yaitu kendala yang biasa dihadapi perusahaan adalah proses pembayaran yang dilakukan oleh pembeli atau pelanggan sering terlambat,terkadang barang telah sampai di tempat atau kantor tetapi proses pembayarannya belum selesai.

\subsection{Saran}

Berdasarkan hasil pembahasan yang telah dikemukakan oleh penulis mengenai Prosedur Penjualan Alat Berat (Toyota Forklift) pada PT Traktor Nusantara Cabang Makassar maka penulis memberikan saran sebagai berikut :

1. Prosedur yang telah diterapkan oleh PT Traktor Nusantara Cabang Makassar, agar dapat mempertahankan serta meningkatkan efektitas dalam Prosedur Penjualan Alat Berat (Toyota Forklift) yang sudah ada.

2. PT Traktor Nusantara Cabang Makassar perlu melakukan sosialisasi kepada pelanggan bahwa barang tersebut belum bisa diterima sebelum transaksi selesai.

3. PT Traktor Nusantara Cabang Makassar sebaiknya memberikan jangka waktu kepada pelanggan dalam melakukan traksaksi semisal 1 (satu) bulan setelah barang tersebut 
diterima bahwa pelanggan harus segera melakukan pelunasan barang.

\section{REFERENSI}

Indrias, Anastasia. 2016. Purchase order, Quotation dan Invoce. Retrieved 05,05,2018 From http://anastasiananaa.blogspot.co. id/purchase-order-quotation-daninvoice.html.

Jack, Rachmoez. 2015. Pengertian dan Penjelasan Penjualan. Retrieved 03,20,2018, From http://dominique122.blogspot.co.i d.pengertian-dan-penjelasanpenjualan.html.

J. Wirandi. (2013). Manajemen Perubahan (Management of Change), Cetakan ke-1, Jakarta, Kencana Media Group.

Kamus Besar Bahasa Indonesia. 2013

Moekijat. 2000. Kamus Manajemen. Cetakan Kelima.

Mulyadi. 2016. Sistem Akuntansi. Edisi Keempat. Jakarta Selatan: Salemba Empat.

2103. Sistem Akuntansi. Edisi Ketiga. Cetakan Keempat. Jakarta: Salemba Empat.
Puspitawati, Lilis. 2011. Sistem Informasi Akuntansi. Yokyakarta: Graha Ilmu

Swastha, Basu. 2015. Manajemen Penjualan. Yokyakarta: BPFE.

2015. Manajemen Pemasaran Modern. Yokyakarta: BPFE.

Traknus. 2015. Sejarah Traktor Nusantara. Retrieved 03,20,2018, From https://www.indotrading.com

Teebriz.2017. Pengertian Penjualan Tunai dan Penjualan Kredit.Retrieved 03,21,2018 From http://teebriz.blogspot.co.id/siklus -penjualan-tunai-dan-kredit.html.

Ticoalu, Reynold. 2016. Sistem Penjualan Tunai. Retrieved 03,21,2018 From https://tugasakuntansiperkuliaha n.blogspot.co.id/sistem-penjualantunai.html.

Traknus. 2018. Products. Retrieved 05,05,2018 From http://www.traknus.co.id/product s

Zuhrotul Aini Manzilah. 2017. Tinjauan Disimplin Kerja Karyawan Terhadap PT Traktor Nusantara Cabang Makassar. Tugas Akhir Administrasi Keuangan 